\title{
ENGINEERING STUDIES ON THE FACTORS AFFECTING THE PERFORMANCE OF SHELLING AND GRADING CORN MACHINE
}

\author{
Abdel Wahab ${ }^{1}$, M.K., S.E. Badr ${ }^{2}$ Hanan M.El-shal ${ }^{3}$ and Amany M. El-Safy ${ }^{4}$

\section{ABSTRACT}

The performance of an Italian made combined machine was tested and evaluated for shelling and grading two different Egyptian corn crop varieties. Whereas, the optimum design, and operating parameters were determined in order to increase the mechanical shelling and grading efficiency and machine productivity. The crop was feed at a constant rate of $25 \mathrm{~kg}$ and at the grains recommended moisture content range of $12-14 \%$ (d.b). The shelling unit of the machine was deduced at four different drum speed levels (from 370 up to $820 \mathrm{rpm}$, those corresponding drum linear speeds from 4.84, up to $10.74 \mathrm{~m} / \mathrm{s}$ ). Also, shelling unit was tested under three concave clearance levels (32, 42 and 52mm). While, the grading unit deduced at different cylindrical screen speed levels (from 55, up to $95 \mathrm{rpm}$ corresponding to linear cylinder speeds from 1.38, up to $2.39 \mathrm{~m} / \mathrm{s}$ ). The grading unit was also tested versus different cylindrical screen inclination angle up to 9 degrees. The tested machine performances were evaluated in terms of the grading and cleaning efficiency. In addition, costs per unit weight of production and energy unit requirements were estimated and compared with the traditional shelling and grading methods of corn crop.The obtained results revealed the following important points:

The optimum parameter levels for the mechanical shelling operation were drum speed of $670 \mathrm{rpm}(8.77 \mathrm{~m} / \mathrm{s})$ and concave clearance of 42 mm. These parameters levels were recommended to match the performance of the grading unit. The promising parameters levels for operating the grading both tested crop varieties were $80 \mathrm{rpm}(2.00 \mathrm{~m} / \mathrm{s})$

\footnotetext{
${ }^{1}$ Professor, Agric. Eng., Fac.of Agric., Zagazig Univ.,Egypt.

${ }^{2}$ Senior, Agric. Eng. Res. Inst.(AEnRI), Agric. Res.Centre, Egypt.

${ }^{3}$ Lecturer, Agric. Eng. Dept., Fac. of Agric., Zagazig Univ., Egypt.

${ }^{4}$ Post graduate student, Agric. Eng., Fac. of Agric .,Zagazig Univ., Egypt.
} 
for cylindrical screen speed and 3 degrees for inclination angle.As operating at the optimum parameter levels the highest values of grading efficiency (83.68 and $82.84 \%$ ), grading cleanliness (77.78 and $77.18 \%)$, and machine capacity (0.51 and 0.47 ton $/ h)$ were achieved. for both tested corn varieties, SC10 and TC310 respectively. Also, the lowest values of specific energy consumption (25.94 and 29.29 $\mathrm{kW} . \mathrm{h} / \mathrm{Mg}$ ) and cost (76.12 and $78.28 \mathrm{LE} / \mathrm{ton})$ for both tested corn varieties, $S C 10$ and TC310, respectively.

\section{INTRODUCTION}

orn considered as one of the most important cereal crops in Egypt. It is used in human feeding, industrial aspects for producing corn oil, starch and dry food for animal. The cultivated area ranges from 1.8 to 1.9 million feddans yearly with total grain productivity of 3.7 million ton (Ministry of Agriculture 2008). Shelling, cleaning and grading of corn grain are considered as the most important operations affecting the quality of grains after harvesting. It is known that the manual method of shelling and grading corn is very tedious, time and labor consuming and thus too expensive. Vice versa, the mechanical methods require less time and labour so the operating cost may be reduced. Hence, such care had to be taken to optimize the performance of a shelling, and grading combined machine in order to obtain grains with high quality features and more homogeneous. The kernels damage in maize shelling by rasp-bar cylinder is affected by grain moisture content, cylinder speed, and concave clearance stated by Fouad $\boldsymbol{e t}$ al.(1981).The slop of the sieve is considered a main factor affecting separation efficiency. That efficiency is increased significantly by increasing the sieve slope up to 25 degrees in both vertical and lateral motion. While, in frontal motion it tends to increase with increasing sieve slope at small stroke lengths and decreased at high stroke length. The separating efficiency was increased in the compound motion as the sieve slope is increased in the range of from zero to 20 degrees but at higher slope the separating efficiency was decreased stated by Ismail (1981).The effects of some factors on the productivity of a locally manufactured Rasp- bar corn sheller were studied by Mettwalli et al. (1995). They concluded that 
the unshelled grain losses was $2.81 \%$ the visible grain damage was $5.71 \%$ the invisible damage was $7.19 \%$ and the cost per unit weight of production was about 7.5 L.E/Mg. Furthermore, the previous criteria were at optimum condition included cylinder speed of $10.26 \mathrm{~m} / \mathrm{s}$, moisture content of $20 \%$ (W.B) and clearance ratio ranged from 1.8 to 2.1.The effect of mechanical properties on grading efficiency was studied, and found that the separating efficiency increased by increasing the time of separation from 3 to $12 \mathrm{~min}$, cylinder speed from 375 to $750 \mathrm{osci} / \mathrm{min}$ for vibratory machine and from 50 to $250 \mathrm{rev} / \mathrm{min}$ for rotary machine, and inclination of sieves up to 9 degree stated by Amin (2003). The performance of a developed Bakistan corn sheller machine was studied by Hanan (2007). The results should that the optimum drum speed and concave clearance for shelling both Yellow and White corn varieties were $6.29 \mathrm{~m} / \mathrm{s}(500 \mathrm{rpm})$, and $40 \mathrm{~mm}$ respectively. The aim of the present study is mainly focused on increasing mechanical shelling and grading efficiency and machine productivity for two different corn varieties by reducing total grain losses and damage. To achieve that aim the following objectives were studied:

1-Determining the main operating and design parameters affecting the performance of a combined machine during shelling and grading different varieties of corn. The investigated parameters included (peripheral drum speed, concave clearance, speed of cylindrical screen and cylindrical screen inclination)

2-Estimating and comparing both costs per unit weight of production and energy unit (requirement) with the traditional shelling and grading methods of corn crop.

\section{MATERIALS AND METHODS}

These experiments of the present study were carried out at Gemmiza Research Station, Gharbia Governorate in season 2009-2010, whereas, the effects of main machinery parameters on the performance of the combined shelling and grading corn machine were studied

\section{A-Materials}

\section{Corn Crop}

Two corn varieties namely single hybrid (SC10) and triple hybrid (TC310) were taken under all tests runs. 


\section{Tractor}

Naser tractor of $48 \mathrm{~kW}$ and P.T.O speed of (540 rpm) was used in this study as the power supply source for operating the investigated machine.

\section{The investigated machine}

The investigated machine was Italian made. It is mainly consisted of three main units for shelling, cleaning and grading operations as shown in Fig.(1).

\section{1-Shelling unit}

The tested shelling unit as shown in Fig.2 is consisting of steel drum with a length of $1800 \mathrm{~mm}$, and a diameter of $120 \mathrm{~mm}$. The drum is supported horizontally by two bearings fixed on the frame; it consist of four parts namely: feeding screw, shelling plates, spike tooth, and crash cob unit discharges. In order to convey the shelled grain to the second screw a concave having thickness of $3 \mathrm{~mm}$, hole diameter of $21 \mathrm{~mm}$, and horizontally screw with $48 \mathrm{~mm}$ O.D was used.

\section{2-Cleaning and grading units}

These units include, screw which is equipped vertically to convey the grains towards the grading unit. The later consists of sieving unit of cylindrical screen as shown in Fig.3,4. The total length of cylindrical screen is $200 \mathrm{~cm}$ and divided according to the included round holes diameter into four parts of $(60,50,50$ and $40 \mathrm{~cm})$ excluded holes diameters of $(8,9.5,11$ and $12.5 \mathrm{~mm})$ respectively. Also four discharge spouts for grading grains were included.The power was transmitted from tractor P.T.O. to operate all machine units at different operational speed by mean of pulley and belts..

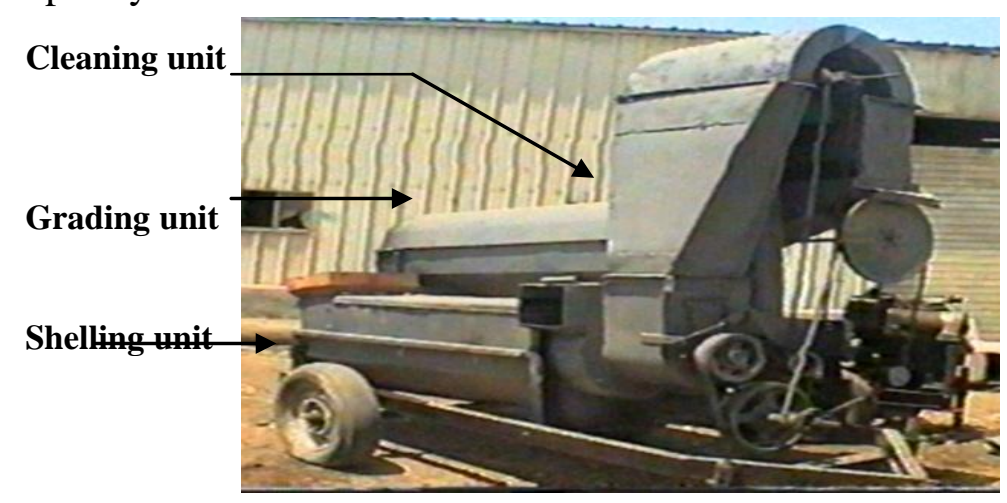

Fig.(1) View of corn combined machine. 


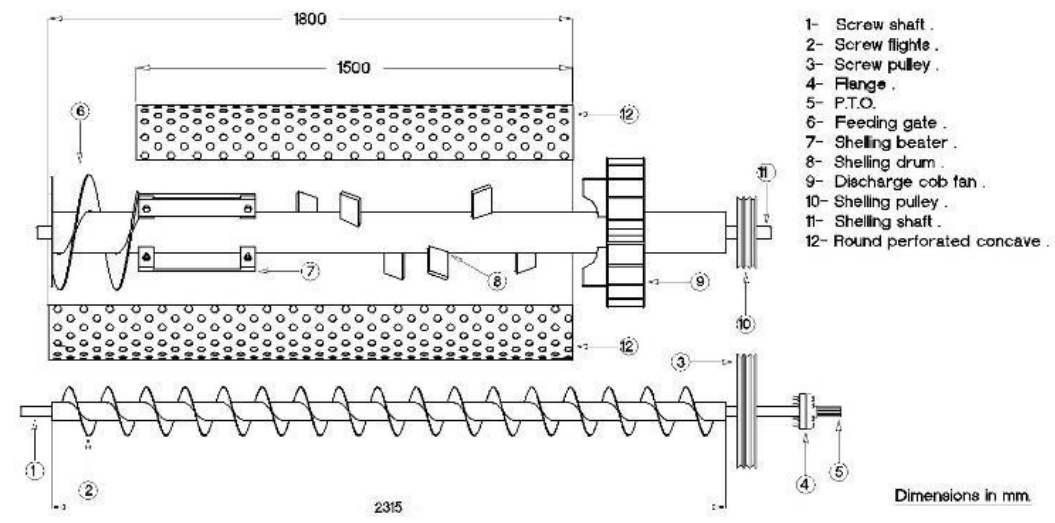

Fig.(2) Elevation view of shelling unit.

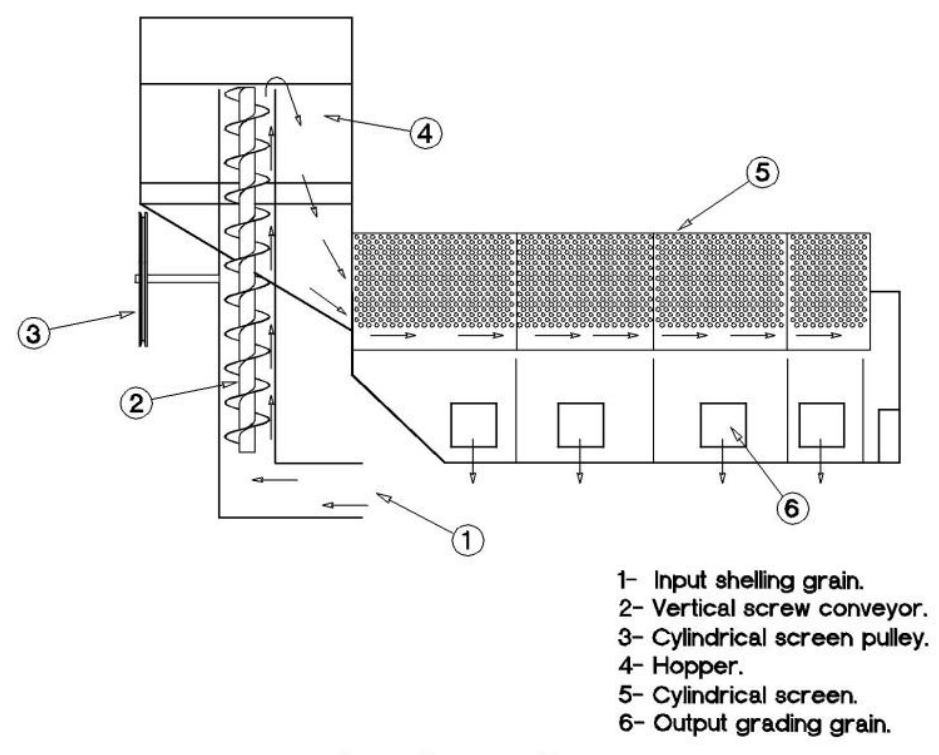

Grading unit

Fig(3) Elevation view of grading unit. 


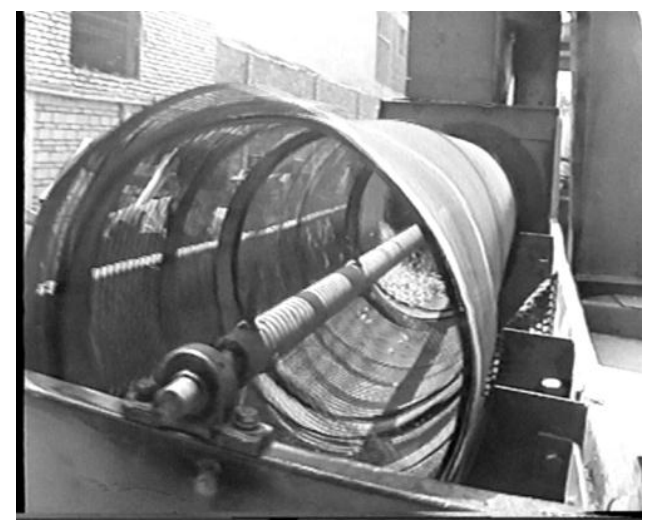

(a)

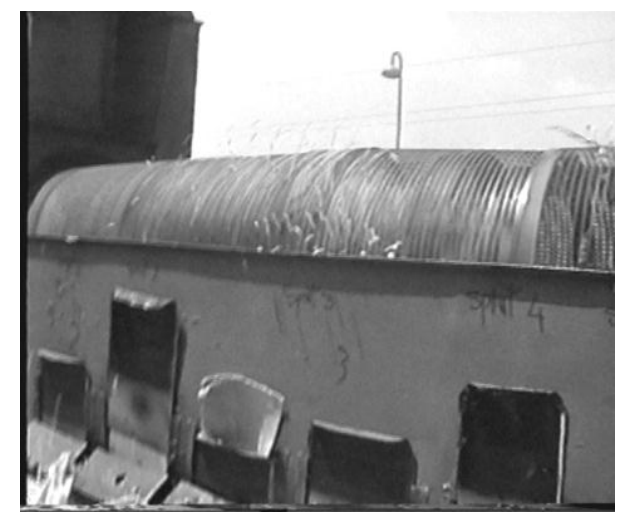

(b)

Grading unit

Discharge spouts

Fig.(4) Views of grading unit and the discharge spouts.

\section{B-Methods}

The crop was feed at constant feeding rate of $25 \mathrm{~kg}$, and the crop was at recommended moisture content range of $12-14 \%$ (d.b). While, the deduced operating and design parameters affecting the performance of tested machine during shelling and grading two different varieties of corn were as follows:

1-For deducing the shelling unit four different drum speed levels were tested namely: ( 370,520,670 and $820 \mathrm{rpm}),(4.84,6.81,8.77$ and 10.74 $\mathrm{m} / \mathrm{s})$, respectively. Also three concave clearance levels of $(32,42$ and $52 \mathrm{~mm}$ ) were evaluated in the shelling unit.

2- For deducing the grading unit, four different cylindrical screen speed levels were evaluated namely: (55,65,80 and $95 \mathrm{rpm}),(1.38 .1 .63,2.00$ and $2.39 \mathrm{~m} / \mathrm{s})$, respectively. In addition, three different inclination angle for cylindrical screen namely: (zero, 3.6 and 9 degrees).

\section{-Measurements}

\section{-Determination of grain damage}

\section{1- Visible grain damage:}

The damaged grains were separated by hand and weighted, and then visible grain damage (\%) was estimated as a percentage of total grain weight as follows: 


$$
\begin{array}{r}
\mathrm{S}_{\mathrm{d}} \\
\text { Wher }
\end{array} \frac{\mathrm{W}_{\mathrm{d}}}{\mathrm{W}_{\mathrm{c}}} \times 100
$$

$\mathrm{S}_{\mathrm{d}}=$ Grain damage, $(\%)$

$\mathrm{W}_{\mathrm{d}}=$ Weight of damage grains, $(\mathrm{g})$

Ws= Total grain weight $(100 \mathrm{~g})$

\section{2-Invisible grain damage:-}

The germination test was used to estimate, the percentage of the invisible grain damage as follows:

Invisible grain damage $(\%)=\mathrm{a} / \mathrm{b} \times 100$

Where:

a: Number of ungerminated grains from the samples taken after machine shelling operations.

b: Total number of grains in the sample.

\section{Shelling losses:}

1-After shelling operations, the unshelled grains were shelled manually from the ears and weighted then unshelled grain percentages were calculated as follows:

$$
\mathrm{L}_{\mathrm{k}}=\frac{\mathrm{W}_{2}}{\mathrm{~W}_{1}+\mathrm{W}_{2}} \times 100
$$

Where:

$\mathrm{L}_{\mathrm{k}}=$ Unshelled grain, \%.

$\mathrm{W}_{1}:=$ Weight of shelled grains, $\mathrm{kg}$.

$\mathrm{W}_{2}$ := Weight of unshelled grains, $\mathrm{kg}$.

$\mathrm{W}_{3}=$ Weight of shelled and received at the outlet of cobs, $\mathrm{kg}$.

2-The free grains which found with the cobs were weighted and then its percentage calculated as follows:

$$
\mathrm{L}_{\mathrm{c}}=\frac{\mathrm{W}_{3}}{\mathrm{~W}_{1}+\mathrm{W}_{2}} \mathrm{X} 100
$$

Total losses $=\left(\mathrm{L}_{\mathrm{k}}+\mathrm{L}_{\mathrm{c}}\right) \%$

Shelling efficiency $(\%)$

Shelling efficiency of corn sheller (E) was estimated as follows:

$$
\mathrm{E}=[100-\mathrm{Lk}]
$$




\section{Grading efficiency $(\%)$}

A randomized sample of 500 grains was taken from each spout for measuring seed width and compare with the hole diameter at the existing cylindrical screen, then the efficiency calculated as follows :

Grading efficiency $=\frac{\text { weight of sample }- \text { weight of (the under and over seeds ) }}{\text { weight of sample }} \times 100$

\section{Cleaning efficiency $(\%)$}

A randomized sample of $1 \mathrm{~kg}$ grains were taken from each spout to calculate seed cleanliness as follows:

Cleaning efficiency $=\frac{\text { weight } \text { of } \text { sample }- \text { weight of impurities }}{\text { weight of sample }} \times 100$

\section{Machine productivity $(\mathrm{Mg} / \mathrm{h})$}

can be determined according to (Amin, 1994) as follows:

$$
W=m_{i} \times \frac{60}{t}
$$

Where:

W: Machine capacity, $\mathrm{Mg} / \mathrm{h}$.

$\mathrm{m}_{\mathrm{i}}$ : Mass of classified crops from the unit, $\mathrm{Mg}$.

$\mathrm{t}$ : Operation time, min.

\section{Fuel consumption $(\mathbf{L} / \mathbf{h})$}

Determined as follows:

$$
F_{\mathrm{C}}=\frac{\mathrm{V}_{\mathrm{f}}}{\mathrm{T}} \times 3.6
$$

Where:

$\mathrm{F}_{\mathrm{c}}$ : Rate of fuel consumption, $\mathrm{L} / \mathrm{h}$.

$\mathrm{V}_{\mathrm{f}}$ : Volume of fuel consumed, $\mathrm{cm}^{3}$.

$\mathrm{T}$ : Time of operation, $\mathrm{s}$.

Power requirements $(\mathrm{Pr}),(\mathrm{kW})$

Estimated by using the following formula according to (Barger $\boldsymbol{e t}$ al., 1963).

$$
\operatorname{Pr}=F c \times \frac{1}{3600} \times \rho_{f} \times L C V \times 427 \times \eta_{t h} \times \frac{1}{75} \times \eta_{m} \times \frac{1}{1.36}
$$

Where:

$\mathrm{F}_{\mathrm{c}} \quad$ : The fuel consumption, $\mathrm{L} / \mathrm{h}$. 
$\rho_{\mathrm{f}} \quad$ : Density of fuel, ( for solar fuel $=0.81 \mathrm{~kg} / \mathrm{l}$ )

$\mathrm{LCV}$ : Lower calorific value of fuel, $\mathrm{kcal} / \mathrm{kg}$, (average 1.c.v. of diesel fuel is $11000 \mathrm{kcal} / \mathrm{kg}$ )

427 : Thermo-mechanical equivalent, kg.m/kcal.

$\eta_{\text {th }}$ : Thermal efficiency of the engine, (considered to be (30-35\%)for diesel engine.

$\eta_{\mathrm{m}} \quad$ : The mechanical efficiency of the engine, (considered to be $80 \%$ for diesel engine).

\section{Energy requirements ,Es (kW.h/mg))}

It was estimated by using the following equation:

$$
E s=\frac{\text { required power }(k W)}{\text { machine productivity }(M g / h)}
$$

\section{Cost analysis}

It was determined considering the conventional method of estimating both fixed and variable costs (kepner, 1982 and Hunt, 1983) according to price level of $2009-2010$.

1- Total costs $\left(\mathrm{T}_{\mathrm{c}}\right)$ :

The total costs, L.E/h are the summation of fixed costs, (L.E/h) and variable costs, (L.E/h) as follow:

Operating costs $(\mathrm{L} . \mathrm{E} / \mathrm{h})=$ Fixed cost $(\mathrm{L} . \mathrm{E} / \mathrm{h})+$ Variable cost $(\mathrm{L} . \mathrm{E} / \mathrm{h})$

Operating costs $(\mathrm{L} . \mathrm{E} / \mathrm{Mg})=$ Total cost $(\mathrm{L} . \mathrm{E} / \mathrm{h}) /$ machine capacity $(\mathrm{Mg} / \mathrm{h})$

A- Fixed costs $\left(F_{c}\right)$ include: depreciation, interest, insurance, taxes and housing.

Deprecation and interest costs have been calculated by using the straight line method as follows:

$$
\text { Deprecation }=\mathrm{P}-\mathrm{S} / \mathrm{N}
$$

Where:

P : Purchase price, L.E.

S : Salvage price, L.E.

$\mathrm{N}$ : Total life in years (h).

$$
\text { Interest }=\frac{(p+s)}{2} \mathrm{X} \frac{r}{100} \quad \text { L.E }
$$

where:

$(p+s) / 2$ : average investment.

r: interest rate $\%$. 
Taxes, insurance and housing (T.I.H) these costs were considered to be $4 \%$ of purchase price (Hunt, 1983).

B- Variable costs (vc) include: repair and maintenance cost, fuel cost and labor cost. Repair and maintenance per hour as percent of the purchase price where considered to be $0.032 \%$ (Kepner, 1982)

Fuel costs $(\mathrm{L} . \mathrm{E} / \mathrm{h})=$ fuel consumption $(\mathrm{L} / \mathrm{h}) \times$ fuel price $(\mathrm{L} . \mathrm{E} / \mathrm{L})$. Lubrication costs $=15 \%$ of fuel costs (Hunt, 1983)

The cost of labour varies with geographic location for hired operators the prevailing wage rate for local labour was found to be $3.57 \mathrm{~L} . \mathrm{E} / \mathrm{h}$, it needs two labours and one driver for the tractor.

\section{RESULTS AND DISCUSSION}

The obtained results from shelling and grading (SC10 and TC310) corn by the combined machine are summarized under the following heads:

\section{Effect of relative peripheral drum speed and concave clearance on: Total grain losses, $(\%)$}

Fig.(5) showed that the total grain losses increases from 3.55 to $6.86 \%$ and from 4.16 to $7.00 \%$ as drum speed increase from 4.84 to $10.74 \mathrm{~m} / \mathrm{s}$ (370 to $820 \mathrm{rpm}$ ) for two varieties of corn (SC10 and TC310) respectively at concave clearance of $32 \mathrm{~mm}$. and the total grain losses increased from 3.55 to $6.83 \%$ and from 4.16 to $7.28 \%$ as concave clearance increase from 32 to $52 \mathrm{~mm}$ at $4.84 \mathrm{~m} / \mathrm{s}$ (370 rpm) drum speed for two varieties under study, this is due to the decrease of unshelled grain and increase of the free grain losses.

\section{Total grain damage, $(\%)$}

Fig.(6) showed that the total grain damage increases from 5.1 to $6.63 \%$ and from 5.64to $7.43 \%$ as drum speed increase from 4.84 to $10.74 \mathrm{~m} / \mathrm{s}$ (370 to820 rpm) for two varieties of corn under study (SC10 and TC310) respectively at concave clearance of $32 \mathrm{~mm}$, this is due to great bulk material at high drum speed which cause high friction and pressure on the grain which in turn will cause more damage. And the total grain damage decreased from 5.1 to $2.35 \%$ and from 5.64 to $2.82 \%$ as concave clearance increase from 32 to $52 \mathrm{~mm}$ at $4.84 \mathrm{~m} / \mathrm{s}$ ( $370 \mathrm{rpm}$ ) drum speed for two varieties under study, the decrease may be attributed to the decrease of friction between kernels at the higher concave clearance 


\section{Shelling efficiency, $(\%)$}

From Fig.(7) the shelling efficiency increased by increasing drum speed and decreasing concave clearance, so using a combined corn machine increased shelling efficiency to (100 and 99.57\%) for shelling two varieties of corn SC10 and TC310 respectively at drum speed of $8.77 \mathrm{~m} / \mathrm{s}$ (670 rpm) and $42 \mathrm{~mm}$ concave clearance, due to the unshelled grain losses decreased.

\section{Effect of Cylindrical Screen Speed and its Inclination Angle on: Grading efficiency, $(\%)$}

Fig.(8) indicated that the grading efficiency increased from 82.26 to $92.64 \%$ and from 81.43 to $91.71 \%$ as cylindrical screen speed decrease from 2.39 to $1.38 \mathrm{~m} / \mathrm{s}$ (95 to $55 \mathrm{rpm}$ ) for corn varieties SC10 and TC 310 respectively at zero inclination degree, this may be due to the grain remain on the screen as long as possible to give every rain an opportunity to pass through an opening. And the grading efficiency decreasing from 92.64 to 85.68 and from 91.71 to $84.82 \%$ as cylindrical screen inclination increase from zero to 9 degrees at $1.38 \mathrm{~m} / \mathrm{s}(55 \mathrm{rpm})$ cylindrical speed. At the optimum value of drum speed $8.77 \mathrm{~m} / \mathrm{s}(670 \mathrm{rpm})$ and concave clearance $42 \mathrm{~mm}$ for shelling operation, this may be due to the grain fall down quickly before the grading operation completed.

\section{Cleaning efficiency, ( \%)}

Fig(9) indicated that the cleaning efficiency increased from 77.02 to $80.24 \%$ and from 76.45 to $79.08 \%$ as cylindrical screen speed increase from 1.38 to $2.39 \mathrm{~m} / \mathrm{s}$ (55 to $95 \mathrm{rpm}$ ) for corn varieties SC10 and TC 310 respectively at zero inclination degree, and also the cleaning efficiency decreased from 80.24 to 77.3 and from 79.56 to $76.58 \%$ as cylindrical screen inclination increase from zero to 9 degrees at $2.39 \mathrm{~m} / \mathrm{s}$ cylindrical speed, at the optimum drum speed of $8.77 \mathrm{~m} / \mathrm{s}(670 \mathrm{rpm})$ and concave clearance of $42 \mathrm{~mm}$ for shelling operation.

\section{Machine productivity, (Mg/h)}

From Fig.10 the machine productivity increased by increasing the cylindrical screen speed and inclination angle, so the increasing of cylindrical screen speed from 1.38 to $2.39 \mathrm{~m} / \mathrm{s}$ (55 to $95 \mathrm{rpm}$ ) tends to increase the machine productivity from 0.32 to $0.47 \mathrm{Ton} / \mathrm{h}$ and from 0.30 to $0.43 \mathrm{Ton} / \mathrm{h}$ for corn varieties SC10 and TC310 respectively at zero 
inclination degree, also the increasing of inclination degrees from zero to 9 degree tends to increase machine productivity from 0.47 to $0.58 \mathrm{Ton} / \mathrm{h}$ and from 0.43 to $0.56 \mathrm{Ton} / \mathrm{h}$ at $2.39 \mathrm{~m} / \mathrm{s}(95 \mathrm{rpm})$ cylindrical speed and the optimum drum speed of $8.77 \mathrm{~m} / \mathrm{s}(670 \mathrm{rpm})$ and concave clearance of $42 \mathrm{~mm}$ for shelling operation.
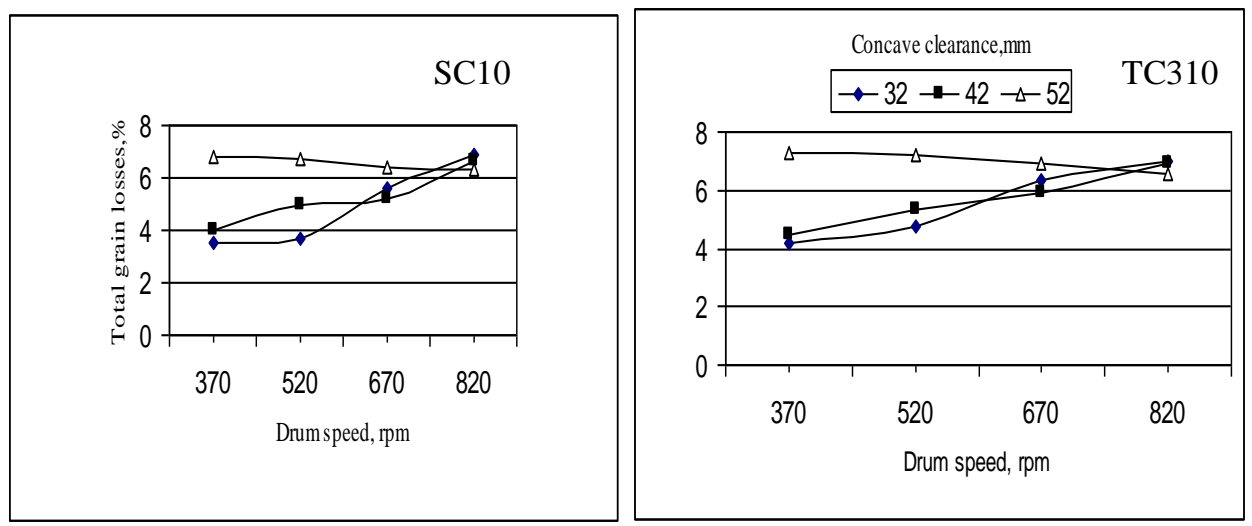

Fig.(5) Effect of relative peripheral drum speed and concave clearance on total grain losses for the corn (SC10 and TC310).
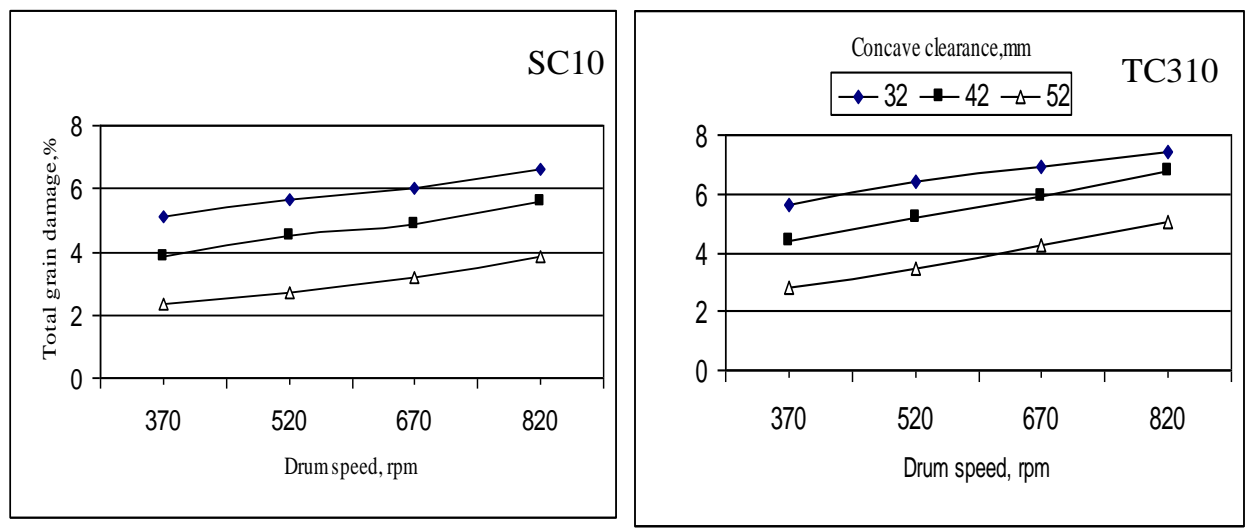

Fig.(6)Effect of relative peripheral drum speed and concave clearance on total grain damage for the corn (SC10 and TC310). 

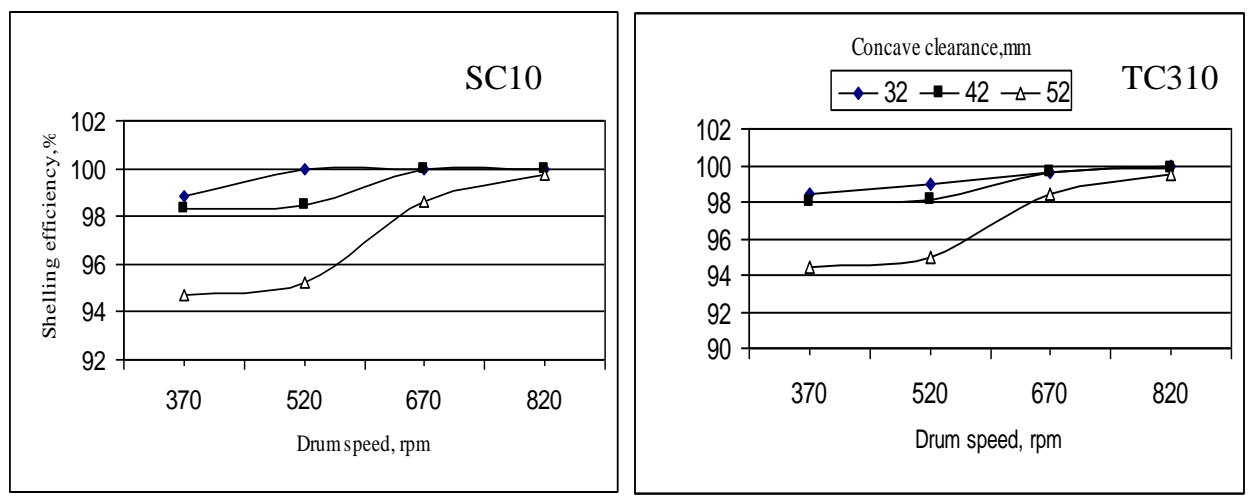

Fig.(7) Effect of relative peripheral drum speed and concave clearance on shelling efficiency for the corn (SC10 and TC310).
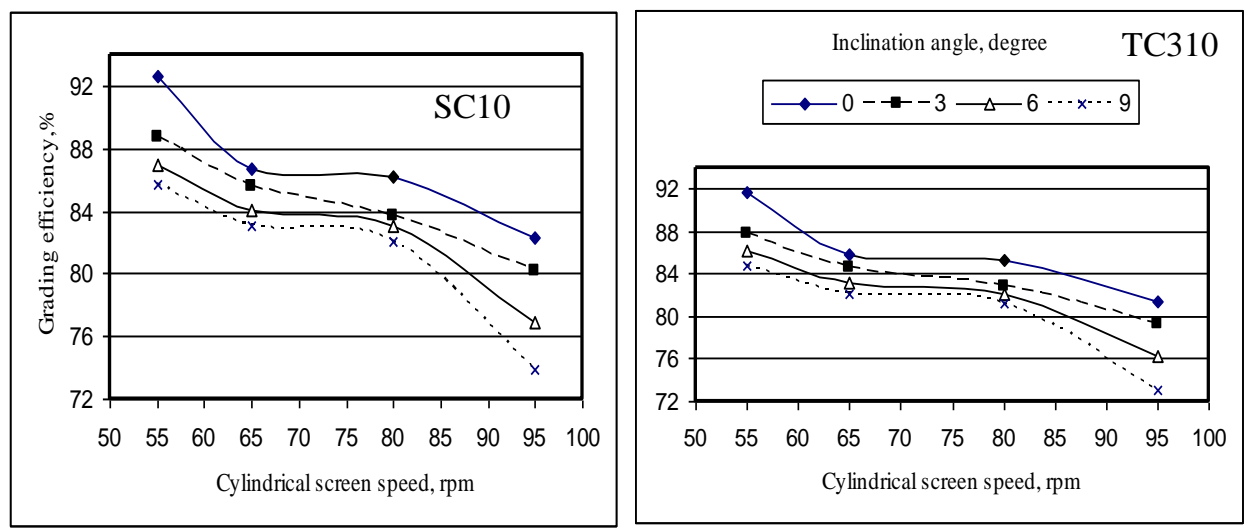

Fig.(8) Effect of peripheral cylindrical screen speed and inclination angle on grading efficiency for the corn (SC10 and TC310)
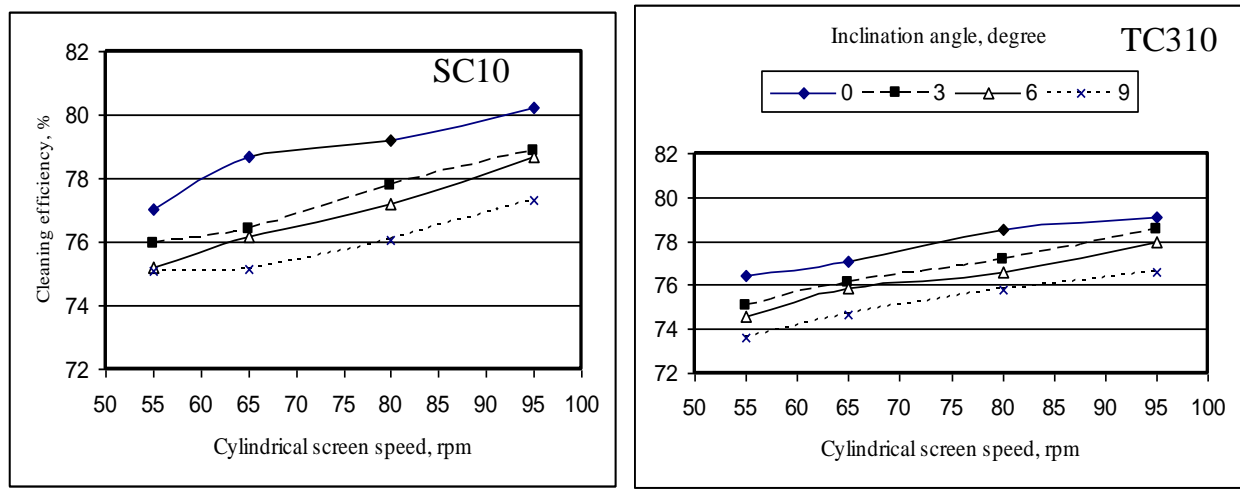

Fig.(9) Effect of peripheral cylindrical screen speed and inclination angle on cleaning efficiency for the corn (SC10 and TC310) 

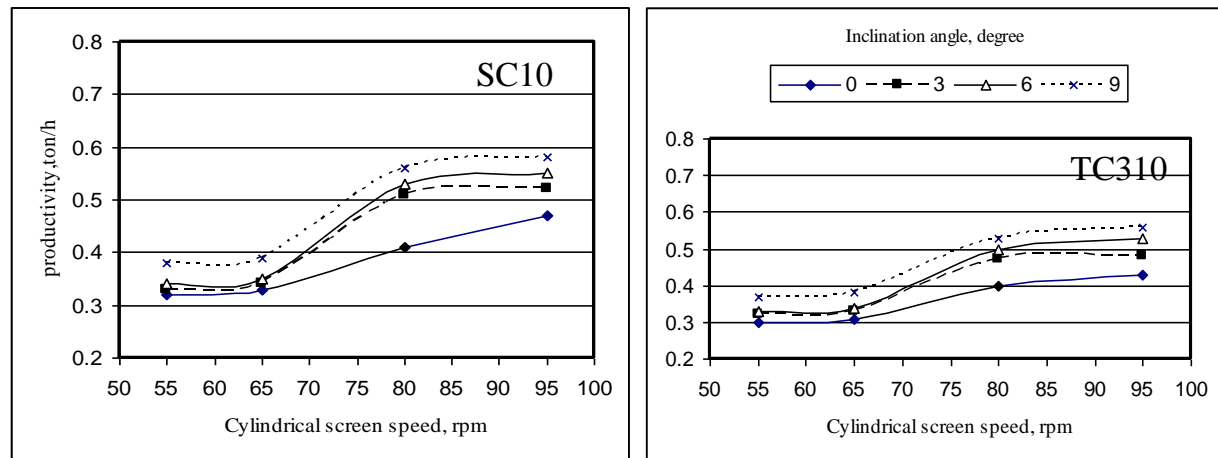

Fig.(10) Effect of peripheral cylindrical screen speed and inclination angle on productivity $\mathrm{Mg} / \mathrm{h}$ for the corn (SC10 and TC310).

\section{Energy requirement, $(\mathrm{kW} . \mathrm{h} / \mathrm{Mg})$}

Results showed that, increasing of cylindrical screen speed and decreasing inclination angle tends to increase the energy requirement at the different operational conditions,so the energy required at the optimum recommended point (drum speed of $8.77 \mathrm{~m} / \mathrm{s}(670 \mathrm{rpm})$, concave clearance of $42 \mathrm{~mm}$ for shelling operation) and( cylindrical screen speed of $2.00 \mathrm{~m} / \mathrm{s}$ (80 rpm) and inclination angle of 3 degrees for grading operation for corn varieties (SC10 and TC310) is 25.94 and $29.29 \mathrm{~kW} . \mathrm{h} / \mathrm{Mg}$ respectively.

\section{-Cost Estimation, (LE/ ton)}

Results showed that the hand shelling and grading operations required 630 L.E/ton, while the cost of mechanical operation required (76.12 and 78.28 L.E/ton) for corn SC10 and TC310 respectively at the optimum recommended point (drum speed of $8.77 \mathrm{~m} / \mathrm{s}(670 \mathrm{rpm})$, concave clearance of $42 \mathrm{~mm}$, cylindrical screen speed of $2.00 \mathrm{~m} / \mathrm{s}(80 \mathrm{rpm})$ and inclination angle of 3 degrees.
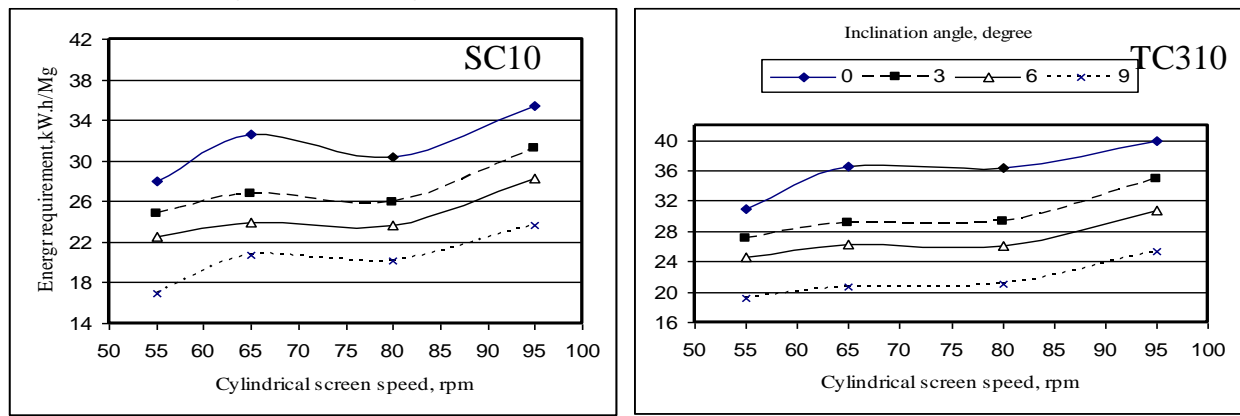

Fig. (11) Effect of peripheral cylindrical screen speed and inclination angle on energy requirements for the corn (SC10 and TC310). 


\section{CONCLUSIONS}

The results concluded that the optimum operating parameters can be used are drum speed of $8.77 \mathrm{~m} / \mathrm{s}$ (670rpm), concave clearance of $42 \mathrm{~mm}$ for shelling operation and cylindrical screen speed of $2.00 \mathrm{~m} / \mathrm{s}(80 \mathrm{r} . \mathrm{p} . \mathrm{m})$ and inclination angle 3 degree for grading operation at SC10 and TC310 this parameters achieved the highest value of grading efficiency of (83.68 and $82.84 \%)$, cleaning efficiency of (77.78 and $77.18 \%)$, machine productivity of $(0.51$ and $0.47 \mathrm{ton} / \mathrm{h})$, the lowest value of total damage is (4.88 and $5.93 \%)$, total losses of (5.22 and $5.93 \%$ ), fuel consumption of (4.92 and $5.12 \mathrm{~L} / \mathrm{h})$, power consumption of (13.23 and $13.77 \mathrm{~kW})$,specific energy of (25.94 and $29.29 \mathrm{~kW} . \mathrm{h} / \mathrm{Mg})$ and cost estimation (76.12 and 78.28 LE/ton) for corn varieties $\mathrm{SC10}$ and $\mathrm{TC} 310$ respectively.

\section{REFERENCES}

Amin,E.A .1994. Development a grading machine for some horticulture farm crops . J. Agric . Sci., Mansoura Univ.,19 (7) : 2399-2411.

Amin, E.E.A. 2003. Effect of some physical and mechanical properties on grading efficiency. The $11^{\text {th }}$ Annual Conference of Misr Society of Agr. Eng. Oct.2003 : 451-470.

Barger,E.I., B.L.Eohi, W.M.Carleton and E.G. Mckibben .1963. Tractor and their power unit. $2^{\text {nd }}$ ed., Wiley and Sons.Inc.,N.Y.

El-shal, H, M.S. 2007. Development of an equipment for corn shelling . Ph.D. Thesis. Agric. Eng. Dept., Fac of Agric Zagazig Univ.

Fouad, H., M.N. Awady, G.B., Hanna, and M. Abou El-Kheir.1981. Optimal operation conditions for shelling maize with a rasp-bar cylinder. J.Col.Agric.Unir.Riyadh,3:31-42

Hunt, D .1983 . Farm power and machinery management. Iowa State University Press, AMER,2nd ed .pp.63-77.

Ismail, F.H .1981. Engineering and technological study on cleaning and grading crops.M.Sc.Thesis, Agric.Mech. Dept., Faculty of Agric., Mansoura Univ.

Kepner, R.A., Roy Bainer and E.L. Barger .1982 .Principles of farm machinery. The AVI Publishing Co.Inc.,West Port, Connecticut, U.S.A; 392-431.

Metwalli,M.M., M.A.Helmy,S.M.Gomma, and M. E. Badawy. 1995. Evaluation of some parameters affecting corn sheller performance. Misr. J. Agric. Eng., 12(2): 439-455. 
الملخص العربى

دراسات هندية عن العوامل المؤثرة على آداء آلة تفريطو تدريج الذرة

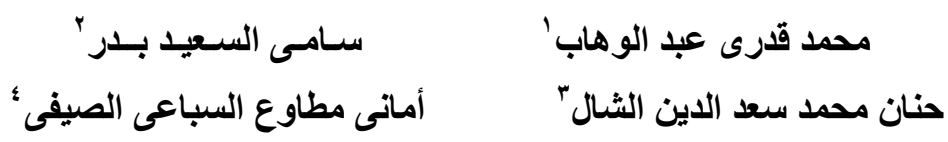

اجريت التجربة في محطة البحوث الزر اعية بالجميزة بمحافظة الغربية خلال الموسم الزر اعي الزي

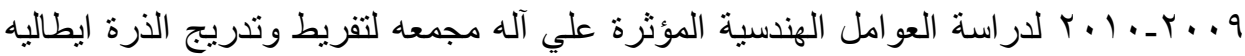

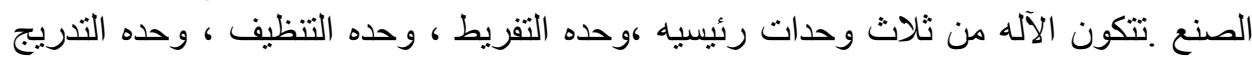

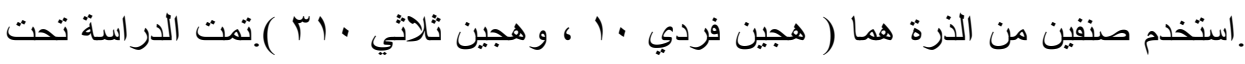

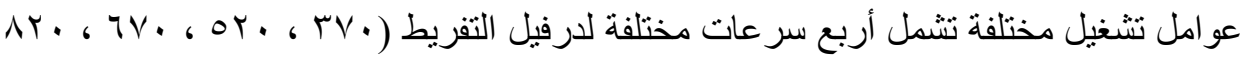

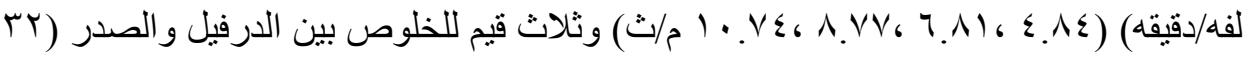

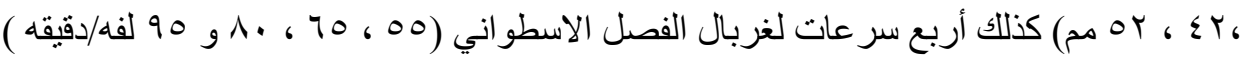

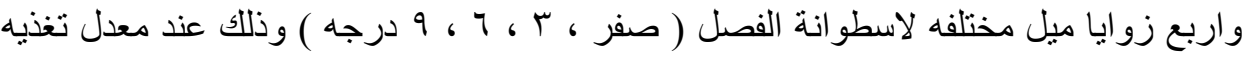

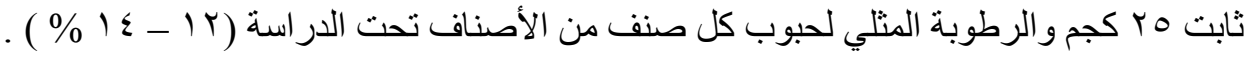

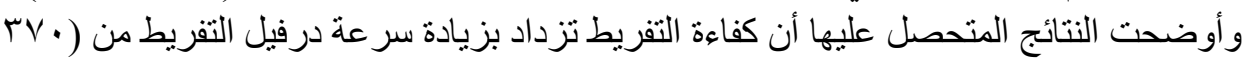

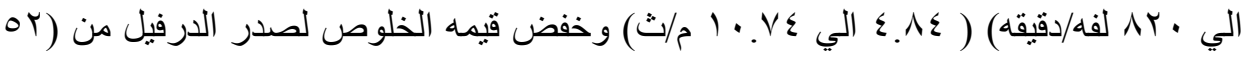

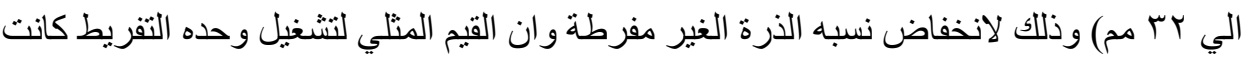

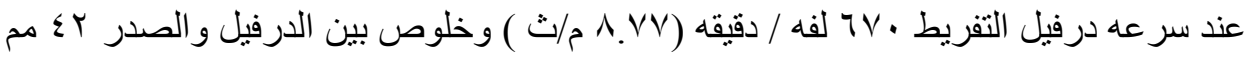

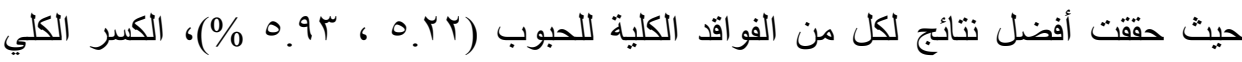

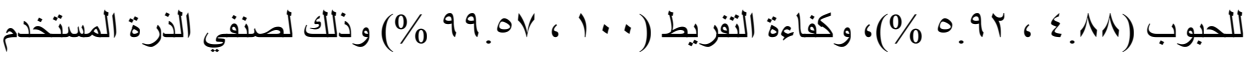

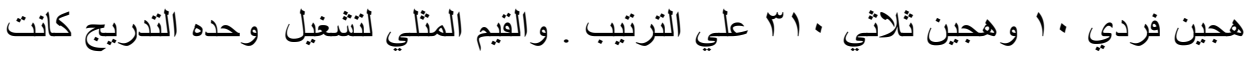

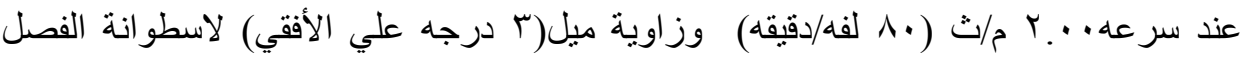

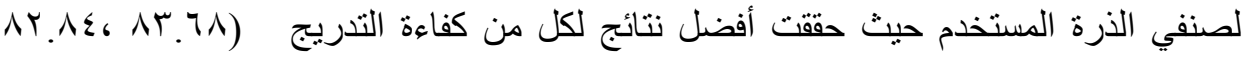

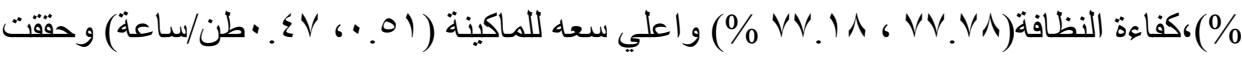

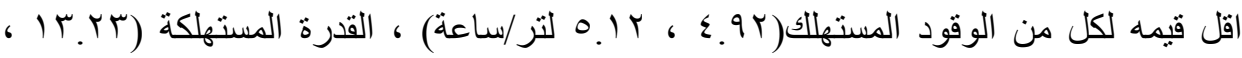

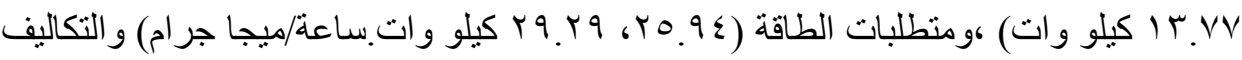

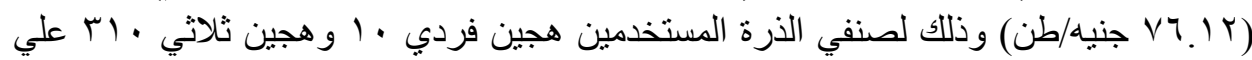
الترنيب . n

'أستاذ الهندسة الزراعية ـ كلية الزراعةـ جامعة الزقازيق - مصر.

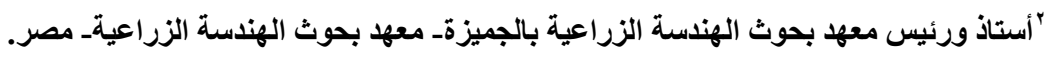

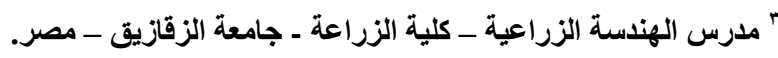

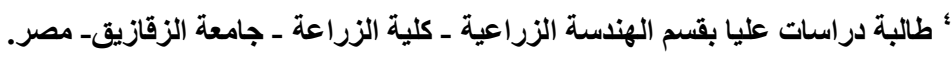

